\title{
Alpha-1 Antitrypsin Deficiency: Principles of Care
}

\section{Deficiência de Alfa-1 Antitripsina: Princípios do Tratamento}

Joana F. RODRIGUES $\square^{1}$, Alexandra MINEIRO ${ }^{2}$, António REIS ${ }^{3}$, David G. VENTURA ${ }^{1}$,

Fernando FERNANDEZ-LLIMOS ${ }^{4}$, Filipa COSTA ${ }^{5}$, Joana GOMES ${ }^{6}$, José Manuel SILVA ${ }^{7}$, Paulo LOPES ${ }^{5}$,

Carlos Robalo CORDEIRO 5

Acta Med Port 2020 Jun;33(6):433-439 - https://doi.org/10.20344/amp.12950

\section{ABSTRACT}

Alpha-1 antitrypsin deficiency is an autosomal co-dominant inherited disorder that results in decreased circulating levels of alpha- 1 antitrypsin (also known as alpha-1 proteinase inhibitor) and predisposes affected individuals to early onset lung and liver disease. There is currently no cure for alpha-1 antitrypsin deficiency. However, appropriate treatment and a high standard of clinical care can prevent patients from being seriously affected and having to undergo major medical interventions, such as organ transplantation. Beyond managing the symptoms associated with alpha- 1 antitrypsin deficiency, alpha- 1 proteinase inhibitor therapy is the only treatment for the condition's underlying cause. Early diagnosis is important to ensure efficient therapeutic strategies and to minimize further deterioration of lung function. alpha-1 antitrypsin deficiency is under diagnosed globally, partly because the disease has no unique presenting symptoms. This document was prepared by a Portuguese multidisciplinary group and it aims to set out comprehensive principles of care for Alpha-1 antitrypsin deficiency. These include the importance of registries, the need for clinical research, the need for consistent recommendations (regarding diagnosis, treatment and monitoring), the role of reference centres, the requirement for sustained access to treatment, diagnostic and support services, and the role of patient organizations.

Keywords: alpha 1-Antitrypsin Deficiency/therapy; Health Care Quality, Access, and Evaluation; Professional Practice; Standard of Care

\section{RESUMO}

A deficiência de alfa-1 antitripsina é uma doença hereditária autossómica co-dominante que resulta numa diminuição dos níveis plasmáticos de alfa-1 antitripsina (também conhecida por inibidor da alfa-1 proteinase) e predispõe os indivíduos afetados ao desenvolvimento de doença pulmonar e hepática precoce. Atualmente não existe cura para a deficiência de alfa-1 antitripsina. No entanto, o tratamento adequado e um elevado padrão de cuidados clínicos podem prevenir que os doentes sejam gravemente afetados e terem que se submeter a intervenções médicas major, como o transplante de órgão. Para além de atuar nos sintomas associados à deficiência de alfa-1 antitripsina, a terapêutica com o inibidor da alfa-1 proteinase é o único tratamento disponível que atua na causa subjacente desta patologia. O diagnostico precoce é importante para assegurar a implementação de estratégias terapêuticas eficientes e para minimizar a destruição adicional da função pulmonar. A deficiência de alfa-1 antitripsina está globalmente sub diagnosticada, em parte devido ao fato desta doença não apresentar sintomas únicos. Este documento foi preparado por um grupo multidisciplinar e visa estabelecer princípios de cuidados abrangentes para a deficiência de alfa-1 antitripsina. Estes incluem a importância dos registros, a necessidade de investigação clinica, a necessidade de recomendações consistentes (no que diz respeito ao diagnostico, tratamento e monitorização), o papel dos centros de referência, a necessidade de acesso sustentado ao tratamento, diagnostico e serviços de suporte, e o papel das associações de doentes.

Palavras-chave: Acesso e Avaliação dos Cuidados de Saúde; Deficiência de alfa 1-Antitripsina/tratamento; Padrão de Cuidado; Qualidade, Prática Profisional

\section{INTRODUCTION}

\section{Why set up a 'principles of care' document?}

Alpha-1 antitrypsin (A1PI) is a proteinase inhibitor mainly synthesized in hepatocytes that inactivates neutrophil elastase to prevent the degradation of elastin and connective tissue in the lung. Alpha-1 antitrypsin deficiency (AATD) is caused by the lack of this protective protein. It can cause severe debilitating diseases, such as chronic liver disease and, specially, pulmonary emphysema.

AATD is a potential life-threatening disease that progressively and irreversibly leads to the destruction of the parenchymal lung tissue of the alveoli and eventually af- fects the elasticity of the structural lung tissue supporting the function of the lungs, thus causing emphysema and dyspnea. The condition frequently prevents patients from working or performing normal activities, thus having a potential negative impact on their quality of life. ${ }^{1,2}$

Lung tissue damage is slow and may not cause symptoms until a significant amount of tissue has been destroyed, a fact which leads to a remarkable delay in the onset of symptoms. Additionally, AATD symptoms are common with other respiratory diseases, such as chronic obstructive pulmonary disease (COPD) or asthma. As a result, patients

\footnotetext{
1. CSL Behring. Lisboa. Portugal.

2. Pulmonary Department. Centro Hospitalar Lisboa Central. Lisboa. Portugal.

3. Pulmonary Department. Centro Hospitalar Tondela-Viseu. Viseu. Portugal.

4. Laboratory of Pharmacology. Department of Drug Sciences. Faculty of Pharmacy. University of Porto. Porto. Portugal.

5. Pulmonary Department. Centro Hospitalar Universitário de Coimbra. Coimbra. Portugal.

6. Pulmonary Department. Centro Hospitalar do Porto. Porto. Portugal.

7. Pulmonary Department. Unidade Local de Saúde da Guarda. Hospital Sousa Martins. Guarda. Portugal.

$\triangle$ Autor correspondente: Joana F. Rodrigues. Joana.Rodrigues@cslbehring.com

Recebido: 11 de outubro de 2019 - Aceite: 10 de março de 2020 | Copyright @ Ordem dos Médicos 2020
} 
are often thought to have other conditions and the diagnosis of AATD is delayed by up to a decade from the onset of symptoms. Thus, the exact prevalence of AATD in most populations is unknown, and many affected individuals remain undiagnosed. The estimated prevalence of AATD is up to $5 \%$ among COPD patients, yet only $4 \%-5 \%$ of those with a deficiency have been identified. ${ }^{3-5}$

As a result, despite being one of the most common genetic conditions affecting people in Western Europe, AATD is rarely diagnosed. Detection rates are especially low in some countries. ${ }^{6}$ This may be related to a lack of awareness of AATD among physicians which significantly delays diagnosis. ${ }^{5}$ It is also important to note that carrying the gene does not inevitably lead to either emphysema or its symptoms.

Early diagnosis enables people with AATD to receive disease-specific support and appropriate treatment, allowing patients to lead a normal and productive life. AATD related emphysema cannot be cured. However, provided the condition is diagnosed at an early stage, deterioration of lung function can be minimized and the progression of emphysema can be slowed down considerably. ${ }^{1,7} \mathrm{~A}$ recent publication demonstrated a 5.8 year extrapolated prolongation of the period before death, lung transplant or severe respiratory condition in favour of $\mathrm{A} 1 \mathrm{PI}$ therapy, which is the only therapy available for this specific condition. ${ }^{8}$

With the aim of providing guidance to stakeholders and decision-makers on how to ensure early diagnosis and to provide the best supportive care and scientific progress in this area, a number of health care policies, practices and services need to be acknowledged, standardised and put into practice.

With this purpose in mind, a Portuguese multidisciplinary group has drawn up this document which outlines comprehensive principles of care for AATD. These include: the importance of registries, the need for clinical research, the need for consistent recommendations (regarding diagnosis, treatment and monitoring), the role of reference centres, the requirement for continued access to treatment, diagnostic and support services and the role of patient organizations.

Implementing these specific measures as a national integrated approach adapted to the specific conditions of each country will ensure that efforts are made towards the common goal that all AATD patients can obtain access to the care they need.

\section{Increasing awareness of AATD}

Increasing awareness is of utmost importance to ensure that symptomatic AATD patients are properly diagnosed, treated and that their quality of life is improved.

Preventive measures are not taken due to the lack of policy initiatives promoting early diagnosis. Such initiatives should include programs to raise awareness of AATD in the medical community and the general public. ${ }^{1}$ The nature of awareness campaigns may vary depending on the specific nature of each country.

Medical awareness plays a key role. Specialists who would get the highest benefit from educational initiatives include practitioners of family medicine, internal medicine, gastroenterology, hepatology and pulmonology. Within the Portuguese health context, these are the specialities that should be involved in the different stages of disease management, from suspicion of the disease to treatment and monitoring.

The awareness of patients and the general public is also important. Patient organizations are crucial to inform and educate the public, health policymakers and decision makers in order to increase the rate of diagnosis and improve treatment access. Greater awareness is essential to warrant that the principles of care set out in this paper can be implemented as broadly as possible.

\section{PRINCIPLES OF CARE}

\section{The importance of registries}

One of the recommendations proposed at the World Health Organization (WHO) meeting on AATD deficiency in 1996 was the establishment of an international AATD coordination registry that would collect data from national registries. ${ }^{9}$ The alpha-1 International Registry (AIR) was created in 1997, resulting in a multinational registry containing data from 18 different countries. AIR has played a central role in raising awareness of AATD and its scientific initiatives (such as international conferences) having fostered collaboration between clinicians dealing with AATD. ${ }^{10}$

In recent decades, a number of countries across the EU and worldwide have implemented registries for AATD. , 11-17 $^{-17}$ They differ widely in their goals, inclusion criteria and follow-up procedures. The development of registries for AATD will a) address many of the gaps in our knowledge of the disorder, b) facilitate understanding of the natural history of AATD, c) promote patient education and dissemination of information, d) facilitate clinical and basic science research of the disease in (and across) countries, and e) foster international collaboration through research initiatives. ${ }^{18,19}$

A good example of these initiatives is Belgium, which joined AIR in 1999, and had set up the first working group in the country, within the Belgian Thoracic Society in 2001, as well as promoted the Belgian AATD registry starting in 2003, when the first Belgian patients were entered into the AIR registry..$^{13}$ The working group was tasked with drawing up national guidelines. The achievement of these milestones and the integrated activities of all stakeholders involved in AATD placed this country on the scene thereby enhancing disease management in Belgium. In 2015, Hutsebaut et al reported that $55 \mathrm{~A} 1 \mathrm{PI}$ deficient subjects had entered the Belgian registry, yielding a prevalence rate of $<1: 50000 .^{13}$

Data from AATD registries have provided important insight into the characteristics of the disease and the level of patient care. Some examples are described below.

An analysis of the German registry ${ }^{20}$ has not found any gender-dependent differences in the clinical presentation of AATD individuals, as opposed to COPD where bronchitis is more common in females, while emphysema is more frequent in males. ${ }^{21}$ The analysis also showed a 
significantly longer delay in diagnosis for female patients. In the Spanish registry ${ }^{22} \mathrm{Pi}^{*} \mathrm{ZZ}$ showed more severe impairment in lung function compared to $\mathrm{Pi}^{*} \mathrm{SZ}$, even with lower levels of tobacco usage and a younger age at baseline, probably due to the earlier onset of symptoms in $\mathrm{Pi}^{\star} \mathrm{ZZ}$ individuals. Data from the Italian registry ${ }^{16}$ showed that patients on A1PI therapy, as compared to untreated patients, included fewer non-smokers; they had a lower percentage of $\mathrm{Pi}^{\star} \mathrm{ZS}$ subjects and more symptomatic patients. The French registry of patients with AATD-associated emphysema $^{23}$ indicated worse health-related quality of life for females, and dyspnea was the most common symptom associated with St. George's Respiratory Questionnaire (SGRQ) score. An analysis of the Canadian AIR registry suggested greater preservation of lung function $\left(\mathrm{FEV}_{1}\right)$ among patients treated with an A1PI compared to non-treated patients. ${ }^{2}$ Another Canadian registry was created in 1999 and has since enrolled 290 symptomatic A1PI deficient patients. If extrapolated over the Canadian population, this would yield an incidence of $<1: 120000 .^{2}$ A similar registry in the UK, where 1 in every 1600 to 5000 newborns is estimated to be susceptible to A1PI deficiency, estimates only a total of 540 symptomatic patients in England (<1 per 120 000), based on 18 years of experience in the Midlands. ${ }^{24}$

A Portuguese registry is currently being set up within the Portuguese Society of Pulmonology with the following aims: to better understand Portuguese epidemiology; to increase awareness of this under diagnosed disease; to encourage research and, ultimately, to improve the quality of care for all patients suffering from this disabling disease.

\section{The need for clinical research}

Clinical AATD research raises awareness of the disease, develops scientific knowledge and facilitates earlier access to therapy. ${ }^{11}$ Among the objectives already mentioned, the goal for registries has also been to foster research and collaboration. It is clear that registries encourage greater understanding of diseases, of their pathogenesis, current management and development of novel therapeutic strategies. ${ }^{10}$ They are indeed an excellent resource for recruiting patients into clinical studies, both observational and clinical trials.

However, it should be kept in mind that registry studies may have several limitations, based on their structures. For example, the German registry ${ }^{20}$, unlike others ${ }^{13,22}$, is based on a questionnaire that is distributed to both patients and physicians, a fact that implies decreased data quality in relation to the data collected from clinical trials or provided only by health care professionals. Additionally, patients are recruited through various pathways that do not represent a well-balanced distribution of phenotypes and disease manifestations. In some registries ${ }^{2,22}$ patient participation is voluntary, and they do not, therefore, reflect the real epidemiological status in such countries. Thus, before drawing any conclusion from studies using registry data, potential sources of bias must be considered.

Registry data have contributed to a meta-analysis eval- uating the impact of $\mathrm{A} 1 \mathrm{PI}$ therapy on lung function. ${ }^{25}$ It has also reduced the hurdle of identifying patients eligible for enrolment in multicentre clinical trials. Interestingly, a unique industry/academic registry was established in the United Kingdom. ${ }^{14}$ This research program encompassed regular meetings (every six months) between experts in the pharmaceutical group and academic researchers. This has fostered synergies and collaboration between academia and industry, which has led to a much clearer understanding of health care delivery aspects. These include economics and the design of clinical trials based on relevance to patients and health care providers, as well as licensing authorities. Also, the alpha-1 Foundation Research Registry has a long history of facilitating research studies in the United States. ${ }^{26}$

The number of patients that each centre can accumulate for research is limited. In fact, even within a single centre it is difficult to select patients for clinical trials, especially when it comes to an under-recognized and underdiagnosed disease. ${ }^{26,27} \mathrm{~A}$ multicentre approach offers the possibility to recruit more patients (larger sample size) and increase the robustness of the results, thereby being more efficient than single-centre research. The multicentre option also has the advantage of speeding up patient recruitment. ${ }^{27}$

It should also be taken into consideration that some studies require large samples. ${ }^{26}$ Databases from registries help researchers to connect with AATD subjects, enabling adequately powered studies.

\section{The need for consistent recommendations (diagno- sis, treatment and monitoring)}

Discrepancies between centres/regions exist in the rate of diagnosis, treatment and patient follow-up. ${ }^{2}$ This is also the case in Portugal.

Because AATD can be a progressive lung disease, early diagnosis can enable clinical discussion and the implementation of treatment options that might slow deterioration of lung tissue. It also allows patients with AATD to promptly implement lifestyle changes, such as smoking cessation, vaccination and increased exercise, in order to prevent lung function decline. . $^{3,28}$

Most AATD patients experience a diagnostic delay after the onset of symptoms, a fact which may lead to further deterioration of lung function. . $23^{23}$ This is likely either to be explained by low awareness of AATD among physicians or the difficulty of differentiating AATD from other common respiratory conditions. It shares major symptoms with COPD and asthma, including shortness of breath during exercise, cough and wheezing. ${ }^{29}$ Indeed, the high prevalence of wheezing in AATD patients may lead to a misdiagnosis of asthma. ${ }^{23}$ However, AATD can be easily diagnosed by determining low A1PI levels from standard serum samples..$^{29-32}$

Measurement of serum A1PI levels or genetic testing is recommended in symptomatic patients in order to establish a correct diagnosis. Initial screening for AATD is usually performed by measuring serum A1PI levels. However, serum A1PI levels do not detect heterozygotes and may overestimate $\mathrm{A} 1 \mathrm{PI}$ levels; $\mathrm{A} 1 \mathrm{PI}$ is an acute phase protein and this 
can mask the presence of AATD.

The American Thoracic Society and European Respiratory Society (ATS/ERS) guidelines advocate targeted testing for AATD in all individuals with: emphysema or COPD; non-responsive asthma; unexplained liver disease; asymptomatic individuals with identifiable risk factors and pulmonary function tests showing persistent obstruction; and adults with necrotizing panniculitis. ${ }^{3}$ This approach has led to higher rates of detection in populations at high risk for lung disease. Nevertheless, under-recognition of this condition is well known to persist. ${ }^{33,34}$ Often, individuals are not screened for AATD because of some common misconceptions about the disease, including:

- AATD is rare (AATD is not rare but merely rarely diagnosed $)^{35}$;

- AATD testing is invasive, expensive and time consuming.

Conversely, diagnostic delay may also be attributed to uncertainty about the role of specific treatments. The first Canadian Thoracic Society statement (1992) concerning specific A1PI therapy recommended that further research was required before A1PI therapy be considered for clinical use. ${ }^{36}$ They stated "a multicentre, placebo-controlled clinical trial should be established to document benefit and safety before this expensive treatment was implemented as standard therapy". On the other hand, the coexisting American Thoracic Society Guidelines ${ }^{37}$ recommend the clinical use of A1PI therapy for all AATD patients with severe lung disease.

The ATS/ERS guidelines recommend intravenous A1PI therapy for individuals with established airflow obstruction from AATD (with clinical evidence of emphysema). ${ }^{3}$ A metaanalysis of available evidence supports A1PI therapy use in patients between $30 \%-65 \%$ predicted $\mathrm{FEV}_{1} \cdot{ }^{25}$ An updated Canadian Thoracic Society statement ${ }^{38}$ cites evidence which supports consideration of A1PI therapy in those individuals with COPD (FEV1 $25 \%$ to $80 \%$ predicted) attributable to emphysema and documented A1PI deficiency (level $\leq 11 \mu \mathrm{mol} / \mathrm{L}$ ) who are receiving optimal pharmacological and nonpharmacological therapies. A recently published document developed by a committee of experts recommends intravenous A1PI therapy in individuals with a FEV1 score lower than or equal to $65 \%$ of predicted value. For those with lung disease related to AATD and a FEV1 score greater than $65 \%$, it is recommended that physicians discuss potential benefits with each individual. ${ }^{39}$

The goal of A1PI therapy is to delay the rate of lung tissue destruction, thereby slowing the progression of lung function decline and the time until severe respiratory failure, potentially leading to lung transplantation or death. A1PI therapy effectively decelerates lung density decline. ${ }^{40}$ Since 1997, several studies with clinical evidence supporting the efficacy of A1PI therapy have been published. The first studies were nonrandomized, controlled clinical trials. ${ }^{41,42}$ Nevertheless, they provided evidence that treatment with an $\mathrm{A} 1 \mathrm{PI}$ is associated with slower $\mathrm{FEV}_{1}$ decline and a decrease in mortality. Subsequently, the results of two randomized clinical trials were published. ${ }^{43,44}$ They were not able to show differences in $\mathrm{FEV}_{1}$ decline between groups, however a trend towards benefit was perceived with decreased lung loss in CT scan for both treatment groups.

In 2015, the world's largest prospective, placebo-controlled trial of A1PI treatment was published (RAPID trial) ${ }^{8}$ establishing, for the first time, the efficacy of A1PI therapy in slowing the progression of emphysema in AATD. The RAPID open label extension study ${ }^{45}$ supports the continued efficacy of A1PI in slowing disease progression during four years of treatment. A consistent disease-modifying effect of A1PI treatment was shown. Delaying treatment resulted in irreversible loss of lung tissue, highlighting the importance of early intervention with $\mathrm{A} 1 \mathrm{PI}$ treatment.

The first preparation of A1PI was approved in 1987, both in the US and Europe, and it was the only AATD-specific treatment on the market until the early 2000s, when other products received approval. ${ }^{46,47}$ Until recently, there was only one treatment available in Europe (a first generation A1PI), but on 20 August 2015 a second generation A1PI was approved for the first time in Europe.

There is a need for increased awareness and screening for AATD and consistent guidance on how/when to treat and follow AATD patients. These actions could potentially improve health outcomes, preserve quality of life, and allow for important life planning for affected individuals.

In order to address these gaps, a Portuguese consensus document concerning the management of alfa- 1 antitrypsin deficiency has been published. It expresses a national consensus for AATD of an expert group created within the Portuguese Society of Pulmonology. The document provided general guidance and extensive recommendations for the diagnosis and management of AATD. ${ }^{48}$

\section{The role of reference centres}

Although national centres follow internationally agreed standards of care, they may vary depending on geography, available resources and expertise. In an ideal world, patients should be referred towards reference centres, a place suitable for patient referral due to its expertise and scope of services. The GOLD document (2017) recommends that AATD family members should be screened and, together with the patient, referred to a specialist centre for advice and management. ${ }^{49}$

Reference centres are built around specialized teams offering multidisciplinary care to patients. These medical centres ensure timely diagnosis and appropriate follow-up by aiming to improve the continuity and coordination of care through the implementation of healthcare pathways and research. ${ }^{50}$ The continuity of care through all stages of the disease and all stages of life is ensured by these centres. ${ }^{51}$

The existence of reference centres implies that the distance between the patient's home and the centre should not be too far and that it should be located in the area corresponding to the patient's health care system for reimbursement purposes. ${ }^{52}$

Reference centres can strongly contribute to research, 
as they provide a pool of patients for clinical studies. ${ }^{14,52}$ It was previously reported that a decentralized care structure makes it difficult to obtain well controlled data from the centres in order to perform clinical studies. ${ }^{20}$ As a result, AATD patients should be managed in these regional centres so as to provide equal access to timely and high quality health services.

In the absence of such formally approved reference centres for AATD, as is the case in Portugal, formal networks should at least be put into place between centres with recognized referral pathways. The existence of such formal links is important to promote best standards of care and to stimulate the dissemination of guidelines, thus facilitating patient registration and allowing professional AATD leadership.

\section{The requirement for sustained access to treatment, diagnostic and support services}

While it is recognized that patients should have access to therapies for their condition, a lack of understanding of AATD is one of the main reasons why these patient's needs are still frequently not fulfilled. Differing perceptions of the disease have led to inequalities between countries and regions, which have resulted in patients being denied A1PI therapy in most European Union member states. ${ }^{1}$

In addition, the AATD diagnosis is often delayed and, consequently, patients do not receive timely treatment. $\mathrm{Pa}$ tient access to early screening measures is therefore essential. ${ }^{1}$

Although $\mathrm{A} 1 \mathrm{PI}$ is the only therapy available for this specific condition, some patients requiring A1PI therapy experienced difficulties in obtaining the treatment. ${ }^{1}$ However, a number of studies have provided clinical evidence supporting the efficacy of A1PI therapy. $8,41-44$

In some countries, A1PI therapy remains inaccessible for patient use due to concerns about the clinical benefits of treatment, commonly associated with its high cost and the lack of reimbursement by the Health Services. ${ }^{11,15}$ Data from the Italian registry has shown that, among subjects with severe AATD and lung disease, the majority of patients were not being treated. It has been suggested that this reluctance to prescribe is related to the costs of treatment. ${ }^{16}$ The Canadian registry revealed a pronounced regional disparity in the number of patient referrals to the registry and in the number of patients receiving A1PI therapy. The authors suggested that these differences most likely reflect variations in: a) the locations of centres with an interest in this condition, b) provincial funding policies concerning A1PI therapy and genetic testing, c) the availability of respiratory specialist care and d) funding for lung function testing. ${ }^{2}$ To avoid these disparities, an individual therapy decision should always be made.

A1PI preparations are derived from pooled human plasma and are usually administered weekly by intravenous infusion at a dosage of $60 \mathrm{mg} / \mathrm{kg}$ body weight. Taking into account the current setting in Portugal, this means that patients need to travel from their homes to the centres where A1PI therapy is administered and, for some patients, this may be very challenging, as their houses are located far away from the centre and they frequently experience economic difficulties. One possible solution may involve AATD patients obtaining A1PI therapy from the patients' primary healthcare centre or having a nurse administering it at home.

On the other hand, some patients may prefer to selfadminister their A1PI therapy rather than having to attend a clinic to receive treatment. The decision of whether a patient is suitable for home-treatment/self-administration is made by the treating doctor. The first infusions should be administered under the supervision of a healthcare professional experienced in the treatment of AATD. When this is planned, the patient's healthcare professional should ensure that instructions and training for performing IV infusion at home or other settings are provided. Subsequent infusions can then be administered by a caregiver or by the patient and reviewed at regular intervals..$^{53}$

\section{The role of patient organizations}

Nowadays, patient organizations have a special impact in society, as they aid patients to manage their disease, provide information about specific health conditions and play special roles in health care policies. They create awareness for the disease(s) by calling attention to the challenges that patients and their families face daily. In turn, disease awareness enables more people to be diagnosed. Patient organizations had initially focused on self-help and charitable support for patients, but later on, attention turned to the need to play a more political role, including raising media awareness. $^{54}$

Patients find important support in organizations, as they break their isolation. In fact, several organizations are creating websites, blogs and online forums for people to come together and share experiences and disease-related concerns. Some websites include educational materials for patients and healthcare professionals, information about diagnosis and contact details for local AATD experts. ${ }^{55}$ Close interaction with patients and their families allows for the sharing of their thoughts and concerns with those organizations responsible for patient empowerment.

One example of an organization giving online support is alpha-1 Global, which has created an internet platform with access for patients, medical and care professionals and researchers to communicate about the disease. ${ }^{56}$

In 2003, the Barcelona Declaration of Patients' Associations established that patients should have access to quality information provided by professionals, mainly physicians, which is written in an easily understandable fashion. It was also stated that decisions on health interventions should be guided by medical judgment based on the best available scientific knowledge, but always taking into account the expressed wishes of the patient and their explicit preferences regarding quality of life and the expected results of interventions. ${ }^{57}$

Patient organizations have an important role in the enforcement of approved laws and should encourage 
improved communication between patients, health care structures, the scientific community and the policy makers. ${ }^{57}$ The European Patient's Forum affirms that they are "Europe's strongest collective patient voice" and promote educational seminars, policy initiatives and projects. The Forum works to improve the openness, transparency and responsiveness of EU decision-making. ${ }^{58}$ EURORDIS (European Organisation for Rare Diseases) supports the development of European policies on rare diseases by gathering patient organizations of each European country together. ${ }^{59}$ At EMA (European Medicines Agency), the management board includes two patients and user group representatives. ${ }^{54}$

Patient organizations also play a role in research funding, facilitating further research and guiding where money should be spent. ${ }^{60}$ Since it was created in 1995, the alpha-1 Foundation has raised nearly 60 million U.S. dollars to help find a cure for alpha-1. The funds were distributed to diverse areas of research, mostly basic research, clinical research and novel therapies. ${ }^{61}$

Patient organizations have a close interaction with different stakeholders. In addition to health care departments, industry and research organizations are important for the work of patient organizations. ${ }^{62}$

\section{REFERENCES}

1. The Alpha-1 Expert Group Initiated and Chaired by Members of the European Parliament. Alpha-1 in the European Union Expert Recomendations. [accessed 2018 Jun 30]. Available from: www.alpha1. uk/wp-content/uploads/2013/08/Alpha1-in-the-European-Union-ExpertRecommendations_electonic-copy.pdf.

2. Bradi AC, Audisho N, Casey DK, Chapman KR. Alpha-1 antitrypsin deficiency in Canada: regional disparities in diagnosis and management. COPD. 2015;12:15-21.

3. American Thoracic Society, European Respiratory Society. American Thoracic Society/ European Respiratory Society statement: standards for the diagnosis and management of individuals with alpha-1 antitrypsin deficiency. Am J Respir Crit Care Med. 2003;168:818-900.

4. Brode SK, Ling SC, Chapman KR. Alpha-1 antitrypsin deficiency: a commonly overlooked cause of lung disease. CMAJ. 2012;184:1365-71.

5. Stoller JK, Sandhaus RA, Turino G, Dickson R, Rodgers K, Strange C. Delay in diagnosis of alpha1-antitrypsin deficiency: a continuing problem. Chest. 2005;128:1989-94

6. Luisetti M, Seersholm N. Alpha1-antitrypsin deficiency. 1: epidemiology of alpha1-antitrypsin deficiency. Thorax. 2004;59:164-9.

7. Petrache I, Hajjar J, Campos M. Safety and efficacy of alpha-1antitrypsin augmentation therapy in the treatment of patients with alpha1-antitrypsin deficiency. Biologics. 2009;3:193-204.

8. Chapman KR, Burdon JG, Piitulainen E, Sandhaus RA, Seersholm N, Stocks JM, et al. Intravenous augmentation treatment and lung density in severe alpha1 antitrypsin deficiency (RAPID): a randomised, doubleblind, placebo-controlled trial. Lancet. 2015;386:360-8.

9. Alpha 1-antitrypsin deficiency: memorandum from a WHO meeting. Bull World Health Organ. 1997;75:397-415.

10. Stockley RA, Luisetti M, Miravitlles M, Piitulainen E, Fernandez P, Alpha One International Registry g. Ongoing research in Europe: Alpha One International Registry (AIR) objectives and development. Eur Respir J. 2007;29:582-6.

11. O'Brien ME, Pennycooke K, Carroll TP, Shum J, Fee LT, O'Connor $\mathrm{C}$, et al. The impact of smoke exposure on the clinical phenotype of alpha-1 antitrypsin deficiency in Ireland: exploiting a national registry to understand a rare disease. COPD. 2015;12:2-9.

12. Koczulla R, Bittkowski N, Andress J, Greulich T, Schroth S, Kotke V, et al. Das Deutsche register fur personen mit Alpha-1-antitrypsin-Mangel-eine tessource fur die versorgungsforschung. Pneumologie. 2008;62:655-8.

13. Hutsebaut J, Janssens W, Louis R, Willersinn F, Stephenne X, Sokal $\mathrm{E}$, et al. Activity of the alpha-1 antitrypsin deficiency registry in Belgium. COPD. 2015;12:10-4

\section{CONFLICTS OF INTEREST}

Alexandra Mineiro received lecture fees from CSL Behring and Menarini. António Reis received lecture fees from AstraZeneca, Bial, Boehringher Ingelleim, CSL Behring, GSK, Medinfar, Mylan, Mundipharma, Novartis, Tecnifar Teva, Zambon, Grifols. Fernando Fernandez-Llimos received lecture fees from Astra Zeneca, Pfizer, Eisai and CSL Behring. Filipa Costa reports personal fees from CSL Behring, and Grifols. Joana Gomes received travel grants from Grifols and lecture fees from CSL Behring and Grifols. José Manuel Silva travel grants from Grifols and Novartis; lecture fees from AstraZeneca, Medinfar, Menarini, Novartis and Glaxo Smith Kline. Carlos Robalo Cordeiro received lecture fees from CSL Behring. Joana F. Rodrigues and David G. Ventura are staff of CSL Behring. Paulo Lopes has no conflict of interests.

These Principles of Care equally commented the two only therapeutic alternatives approved in Portugal for the alpha-1 antitrypsin deficiency. No comparisons were made between these two alternatives.

14. Stockley RA. Antitrypsin Deficiency Assessment and Programme for Treatment (ADAPT): The United Kingdom Registry. COPD. 2015;12:638.

15. Piitulainen E, Tanash HA. The clinical profile of subjects included in the Swedish National Register on Individuals with Severe Alpha 1-Antitrypsin Deficiency. COPD. 2015;12:36-41.

16. Luisetti M, Ferrarotti I, Corda L, Ottaviani S, Gatta N, Tinelli C, et al Italian registry of patients with alpha-1 antitrypsin deficiency: general data and quality of life evaluation. COPD. 2015;12:52-7.

17. Chorostowska-Wynimko J, Struniawski R, Sliwinski P, Wajda B, Czajkowska-Malinowska $\mathrm{M}$. The national alpha-1 antitrypsin deficiency registry in Poland. COPD. 2015;12:22-6.

18. Luisetti M, Miravitlles M, Stockley RA. Alpha1-antitrypsin deficiency: a report from the $2^{\text {nd }}$ meeting of the Alpha One International Registry, Rapallo (Genoa, Italy), 2001. Eur Respir J. 2002;20:1050-6.

19. Stoller JK, Brantly M, Fleming LE, Bean JA, Walsh J. Formation and current results of a patient-organized registry for alpha(1)-antitrypsin deficiency. Chest. 2000;118:843-8.

20. Fahndrich S, Herr C, Greulich T, Seibert M, Lepper PM, Bernhard N, et al. Sex differences in alpha-1-antitrypsin deficiency lung diseaseanalysis from the German registry. COPD. 2015;12:58-62.

21. Han MK, Postma D, Mannino DM, Giardino ND, Buist S, Curtis JL, et al. Gender and chronic obstructive pulmonary disease: why it matters. Am J Respir Crit Care Med. 2007;176:1179-84.

22. Lara B, Miravitlles M. Spanish Registry of Patients With Alpha-1 Antitrypsin Deficiency; Comparison of the Characteristics of PISZ and PIZZ Individuals. COPD. 2015;12:27-31.

23. Gauvain C, Mornex JF, Pison C, Cuvelier A, Balduyck M, Pujazon MC, et al. Health-related quality of life in patients with alpha-1 antitrypsin deficiency: the French experience. COPD. 2015;12:46-51.

24. National Institute for Health Research. Alpha-1 antitrypsin (Respreeza) for emphysema associated with alpha-1 antitrypsin deficiency maintenance therapy. [accessed 2018 Jun 20]. Available from: http:// www.io.nihr.ac.uk/wp-content/uploads/migrated/2709.a214236d. Alpha1antitrypsin_Nov14.pdf.

25. Chapman KR, Stockley RA, Dawkins C, Wilkes MM, Navickis RJ. Augmentation therapy for alpha1 antitrypsin deficiency: a meta-analysis. COPD. 2009;6:177-84.

26. Strange C, Monk R, Schwarz L, Walker D, Kumbhare S, Bieko T. The United States Alpha-1 Foundation Research Registry: genesis, impact and future. COPD. 2015;12:42-5.

27. Sprague S, Matta JM, Bhandari M; Anterior Total Hip Arthroplasty 
Collaborative (ATHAC) Investigators, Dodgin D, Clark CR et al. Multicenter collaboration in observational research: improving generalizability and efficiency. J Bone Joint Surg Am. 2009;91:80-6.

28. Kohnlein T, Welte T. Alpha-1 antitrypsin deficiency: pathogenesis, clinical presentation, diagnosis, and treatment. Am J Med. 2008;121:39.

29. Brantly ML, Paul LD, Miller BH, Falk RT, Wu M, Crystal RG. Clinical features and history of the destructive lung disease associated with alpha-1-antitrypsin deficiency of adults with pulmonary symptoms. Am Rev Respir Dis. 1988;138:327-36.

30. McElvaney NG, Stoller JK, Buist AS, Prakash UB, Brantly ML, Schluchter MD, et al. Baseline characteristics of enrollees in the National Heart, Lung and Blood Institute Registry of Alpha 1-Antitrypsin Deficiency. Alpha 1-Antitrypsin Deficiency Registry Study Group. Chest. 1997;111:394-403.

31. Janus ED, Phillips NT, Carrell RW. Smoking, lung function, and alpha 1-antitrypsin deficiency. Lancet. 1985;1:152-4.

32. Hogarth DK, Rachelefsky G. Screening and familial testing of patients for alpha 1-antitrypsin deficiency. Chest. 2008;133:981-8.

33. Carroll TP, O'Connor CA, Floyd O, McPartlin J, Kelleher DP, O'Brien G, et al. The prevalence of alpha-1 antitrypsin deficiency in Ireland. Respir Res. 2011;12:91.

34. Luisetti M, Massi G, Massobrio M, Guarraci P, Menchicchi FM, Beccaria $M$, et al. A national program for detection of alpha 1-antitrypsin deficiency in Italy. Gruppo I.D.A. Respir Med. 1999;93:169-72.

35. de Serres FJ. Alpha-1 antitrypsin deficiency is not a rare disease but a disease that is rarely diagnosed. Environ Health Perspect. 2003;111:1851-4.

36. Ad Hoc Committee on Alpha-1-Antitrypsin Replacement Therapy of the Standards Committee, Canadian Thoracic Society. Current status of alpha-1-antitrypsin replacement therapy: recommendations for the management of patients with severe hereditary deficiency. CMAJ. 1992;146:841-4.

37. American Thoracic Society. Guidelines for the Approach to the Patient with Severe Hereditary Alpha-1-Antitrypsin Deficiency. Am Rev Respir Dis. 1989;140:1494-7.

38. Marciniuk DD, Hernandez P, Balter M, Bourbeau J, Chapman KR, Ford GT, et al. Alpha-1 antitrypsin deficiency targeted testing and augmentation therapy: a Canadian Thoracic Society Clinical Practice Guideline. Can Respir J. 2012;19:109-16.

39. Sandhaus RA, Turino G, Brantly ML, Campos M, Cross CE, Goodman K, et al. The Diagnosis and management of alpha-1 antitrypsin deficiency in the adult. Chronic Obstr Pulm Dis. 2016;3:668-82.

40. Wewers MD, Crystal RG. Alpha-1 antitrypsin augmentation therapy. COPD. 2013;101:64-7.

41. Seersholm N, Wencker M, Banik N, Viskum K, Dirksen A, Kok-Jensen $A$, et al. Does alpha1-antitrypsin augmentation therapy slow the annual decline in FEV1 in patients with severe hereditary alpha1-antitrypsin deficiency? Wissenschaftliche Arbeitsgemeinschaft zur Therapie von Lungenerkrankungen (WATL) alpha1-AT study group. Eur Respir J. 1997; 10:2260-3.

42. Survival and FEV1 decline in individuals with severe deficiency of alpha1-antitrypsin. The Alpha-1-Antitrypsin Deficiency Registry Study Group. Am J Respir Crit Care Med. 1998;158:49-59.

43. Dirksen A, Dijkman JH, Madsen F, Stoel B, Hutchison DC, Ulrik CS, et al. A randomized clinical trial of alpha(1)-antitrypsin augmentation therapy. Am J Respir Crit Care Med. 1999;160:1468-72.

44. Dirksen A, Piitulainen E, Parr DG, Deng C, Wencker M, Shaker SB, et al. Exploring the role of CT densitometry: a randomised study of augmentation therapy in alpha1-antitrypsin deficiency. Eur Respir J. 2009;33:1345-53.

45. McElvaney NG, Burdon J, Holmes M, Glanville A, Wark PA, Thompson PJ, et al. Long-term efficacy and safety of alpha1 proteinase inhibitor treatment for emphysema caused by severe alpha1 antitrypsin deficiency: an open-label extension trial (RAPID-OLE). Lancet Respir Med. 2017;5:51-60.

46. Stocks JM, Brantly M, Pollock D, Barker A, Kueppers F, Strange C, et al. Multi-center study: the biochemical efficacy, safety and tolerability of a new alpha1-proteinase inhibitor, Zemaira. COPD. 2006;3:17-23.

47. Louie SG, Sclar DA, Gill MA. Aralast: a new alpha1-protease inhibitor for treatment of alpha-antitrypsin deficiency. Ann Pharmacother. 2005;39:1861-9

48. Lopes AP, Mineiro MA, Costa F, Gomes J, Santos C, Antunes C, et al. Portuguese consensus document for the management of alpha-1antitrypsin deficiency. Pulmonology. 2018;24:1-21

49. Global initiative for chronic obstructive lung disease. Pocket guide to copd diagnosis, management, and prevention: a guide for Health Care Professionals. Fontana: GOLD; 2017.

50. Kole AA, le Cam Y. The added value of centres of expertise for rare disease patients in Europe. Orphanet J Rare Dis. 2010;5:O4.

51. Syed AM, Camp R, Mischorr-Boch C, Houyez F, Aro AR. Policy recommendations for rare disease centres of expertise. Eval Program Plann. 2015;52:78-84.

52. Expert group of the Rare Diseases Task Force. Centres of Reference for rare diseases in Europe: State-of-the-art in 2006 and recommendations of the Rare Diseases Task Force. [accessed 2018 Jun 20]. Available from: www.eucerd.eu/?post_type=document\&p=1334.

53. CSL Behring $\mathrm{GmbH}$. Respreeza - summary of product characteristics (August 2015). [accessed 2018 Jun 20]. Available from: http://www. ema.europa.eu/docs/en_GB/document_library/EPAR_-_Product_ Information/human/002739/WC500193614.pdf.

54. Baggott R, Forster R. Health consumer and patients' organizations in Europe: towards a comparative analysis. Health Expect. 2008;11:85-94.

55. National Human Genome Research Institute. Learning about alpha-1 antitrypsin deficiency (AATD). [accessed 2018 Jun 20]. Available from: https://www.genome.gov/19518992/learning-about-alpha1-antitrypsindeficiency-aatd/.

56. Alpha-1 Foundation. Resources. [accessed 2018 Jun 20]. Available from: https://www.alpha1.org/Alphas-Friends-Family/Resources/Alpha1-Global.

57. Fundació Biblioteca Josep Laporte. Declaración de Barcelona de las Asociaciones de Pacientes. [accessed 2018 Jun 20]. Available from: http://salut-envelliment.uab.cat/dbcn/.

58. European Patients Forum. What we do. [accessed 2018 Jun 20]. Available from: http://www.eu-patient.eu/whatwedo/.

59. EURODIS. EURORDIS - Rare diseases Europe in brief. [accessed 208 Jun 20]. Available from: http://www.eurordis.org/content/brief-0.

60. European Respiratory Society. The role of patient organisations [accessed 2018 Jun 20]. Available from: http://www.erswhitebook.org/ chapters/patient-organisations-and-the-european-lung-foundation/therole-of-patient-organisations/.

61. Alpha-1 Foundation. Research. [accessed 2018 Jun 20]. Available from: http://www.alpha1.org/Research-Investments.

62. Alpha-1 Foundation. Alpha-1 Global. [accessed 2018 Jun 20]. Available from: http://www.alpha-1global.org/. 